\title{
Yield depressions due to lowering of the watertable on sandy soils in the Netherlands
}

\author{
J. M. Groot and A. W. de Jager
}

Koninklijke Nederlandsche Heidemaatschappij, Arnhem, the Netherlands

Received 20 November 1968

\section{Summary}

The moisture supply of a crop is mainly determined by precipitation, moisture holding capacity of the soil and capillary rise from the groundwater into the root zone. Lowering of the watertable, for instance by pumping, will decrease the capillary rise and, as a consequence, crop yields will be affected.

In this article a single parameter has been described, comprising the moisture holding capacity of the root zone and the capillary rise, giving the total water supply capacity and thus being a single characteristic of the drought sensitivity of a soil. Using this parameter, yields of soils with different water supply capacity could be compared and a relation could be derived between this parameter and yields. The study was made for fine sandy soils in the Netherlands. The parameter could not be adapted to yield depressions due to high watertables.

\section{Introduction}

A considerable area of the agricultural land in the Netherlands is classified as drought-sensitive, which indicates that yield depressions occur due to moisture deficiency. The magnitude of these depressions has been the subject of extensive research. Because of the position of the watertable, capillary rise plays an important role but an exact evaluation thereof encounters many difficulties. As a consequence, most investigators have tried to establish a relation between yield depression and watertable only. This relation, however, is strongly influenced by the moisture holding capacity of the root zone. This made it necessary to group soils strictly and to analyse data for each group separately.

Rijtema (1965) published data that made it possible to calculate the capillary rise on fine sandy soils. In addition, he proposed one single parameter describing the possible water supply in relation to the watertable, thus being a single characteristic for the drought sensitivity of a soil. In the following, this parameter has been tested and an attempt has been made to relate it to yield data from the literature.

Besides soil characteristics, amount and distribution of precipitation are major factors determining agricultural yields in the Netherlands. Within the scope of this study, however, it appeared impossible to find a satisfactory correlation between the precipitation during the growing season and yields. This being so, the weather factor was eliminated by using average yields, which implied also the use of average watertables and average values of Rijtema's parameter. This forms an approach of the 
drought sensitivity of soils under average weather conditions in the Netherlands. As Rijtema's parameter is developed to evaluate drought sensitivity, it can not be used to relate yield depressions due to excess of water. This problem, being physically different, will not be covered by this article. The study has been made for the sandy soils in the East and South of the Netherlands. They consist of fine sands with the larger part of the particles sized between $75-210 \mu \mathrm{m}$. All data were derived from the literature; no field investigations have been made.

\section{The $(C+M+S)$ parameter}

In his analysis of the capillary rise Rijtema (1965) discerned three layers in the moisture profile: the effective root zone, the saturated zone below the watertable and the layer between. Each layer stores moisture which is to some extent available to the plant. So the total amount of available moisture may be divided up in the following way:

a. The available moisture in the effective root zone designated by $\mathbf{S}$ which is identical to what is conventionally called the moisture holding capacity of this zone.

b. The amount of moisture called $C$, that is available to the plants by capillary rise. The upward capillary flow will decrease with increasing watertable. For the soils concerned, Rijtema published graphs giving the amount of flow in relation to the vertical distance $\mathrm{z}$ above the watertable. The value of $\mathrm{C}$ also depends upon the length of the growing season of the crop. In a long growing season, more moisture may rise upward to the roots than in a short one.

c. The amount of water $M$ that has to be extracted between the bottom of the root zone and the watertable in order to make capillary rise possible. If moisture is to move upward from the groundwater, a potential gradient must be established in the layer between groundwater and effective root zone, which is achieved by extracting moisture from this layer. The relation between this amount called $\mathbf{M}$ and the thickness $\mathrm{z}$ of this layer, has also been evaluated by Rijtema. Besides its dependence on $\mathrm{z}, \mathrm{M}$ also depends on the moisture characteristics of the layer concerned and its capillary properties.

By summing $\mathrm{C}, \mathrm{M}$ and $\mathrm{S}$ a parameter, called $(\mathrm{C}+\mathrm{M}+\mathrm{S})$, was obtained representing the total amount of moisture available to the plant in relation to the watertable. The parameter will be expressed in millimetres as the individual components are.

\section{Watertable and crop yield}

The relation between crop yield and watertable has been investigated by Sieben et al. (1955) for oats and rye. Their investigations were performed from 1948 to 1953 and covered eight different soil types, distinguished according to the thickness $\mathrm{d}$ of the humous top layer. So for each crop in each year eight curves resulted. These curves were converted by the authors by calculating a $(\mathbf{C}+\mathbf{M}+\mathbf{S})$ value for every combination of $\mathrm{d}$ and depth of watertable below root zone $\mathrm{z}$. In order to be able to do this, assumptions had to be made about the depth $\mathrm{zr}$ of the effective root zone and its moisture holding capacity. Therefore, the effective root zone was taken to be equal to the depth of the humous layer, with $15 \mathrm{~cm}$ added. Maximum and minimum values were imposed on $\mathrm{zr}$, viz 80 and $50 \mathrm{~cm}$. So in most cases the root zone consisted 
of humous sand and non-humous sand both. The moisture holding capacity was taken at $20 \%$ for humous sand and $15 \%$ for non-humous sand.

Below the root zone the soil profile was assumed to consist of non-humous sand with capillary properties equal to those of the non-humous sand used by Rijtema. The watertable was assumed to be constant during the growing season, which means in fact that an average watertable was accepted. The length of the growing season was taken at 120 days.

Fig. 1 gives the results of this conversion for oats in 1949. The yields have been plotted against $(\mathrm{C}+\mathrm{M}+\mathrm{S})$ values; these values range between 140 and $600 \mathrm{~mm}$. As can be seen, there is a strong tendency for all eight curves to coincide. For $(\mathrm{C}+\mathrm{M}+\mathrm{S})$ values greater than about $280 \mathrm{~mm}$ the yields have reached a maximum; below $280 \mathrm{~mm}$ they decrease almost linearly. Fig. 1 allows the drawing of an average curve which has not been given for reasons of clarity. The deviation of Sieben's original data from this average curve amounted to $270 \mathrm{~kg} /$ ha; the deviation of these data from the average curves given by Sieben was $170 \mathrm{~kg} / \mathrm{ha}$. In the first case, however, eight curves could be adapted to eight different sets of data, whereas in the second case one curve had to fit all data. Furthermore, an error of $270 \mathrm{~kg} / \mathrm{ha}$ is still less than $10 \%$ of the recorded maximum yields.

Similar results were obtained for oats and rye in the other years. Fig. 2 presents the average curves for oats, each curve being marked with the number of the year concerned. The horizontal scale has been shortened for practical reasons and the yields have been expressed as percentages. One curve has been added, the one marked with 1951-1953. The data for this curve were taken from Ferrari et al. (1957).

Considering Fig. 2 it can be seen that 1949, having a dry growing season, gives large yield depressions. From precipitation figures only, however, it can not be explained why 1950 , with almost as much rain as 1951 and 1952 , should coincide with 1949 ; 1948 falls even below 1949, although the latter year had less rainfall.

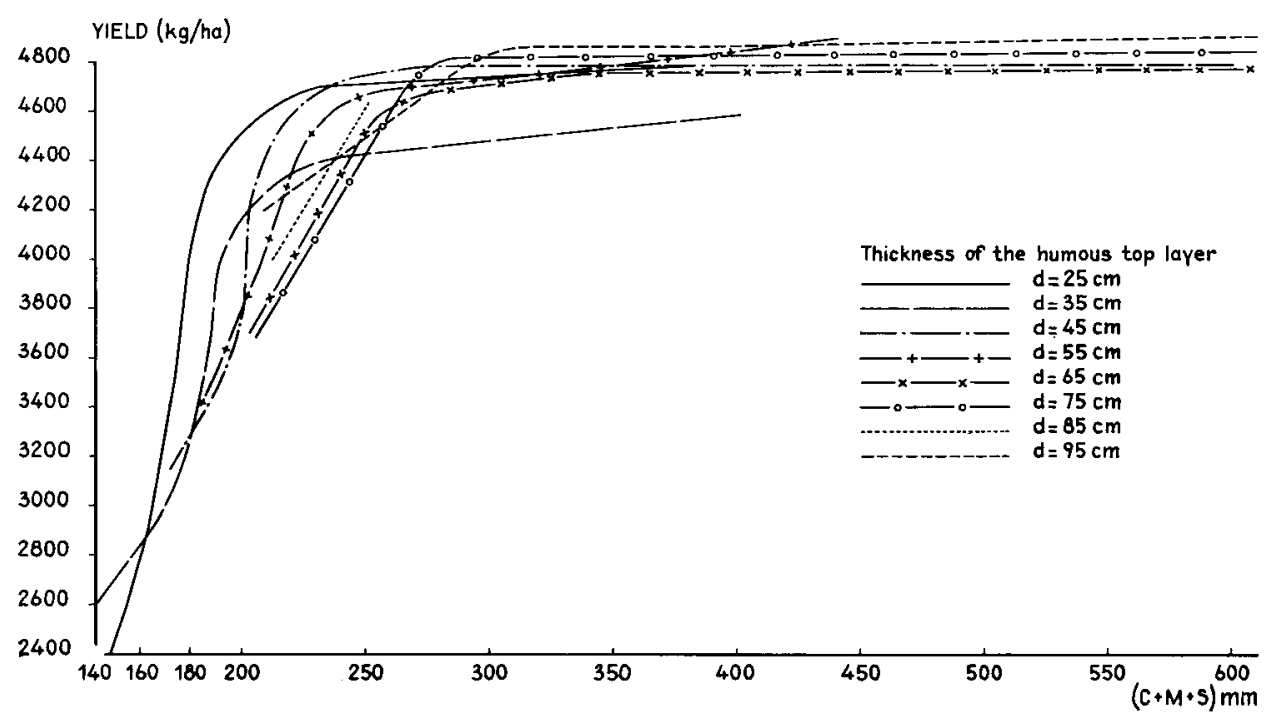

Fig. 1 Relation between $(C+M+S)$ and yields for oats converted from Sieben's 1949 data 


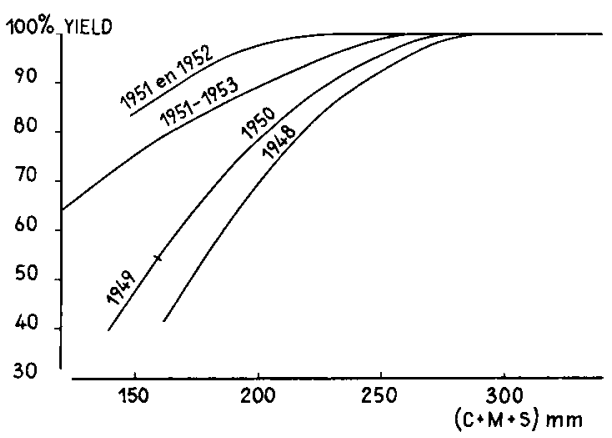

Fig. 2 Relation between $(C+M+S)$ and yields for oats in the years 1948-1953

The results for rye have been given in Fig. 3. In this case all curves were derived from data given by Sieben et al. (1955). Fig. 3 clearly demonstrates that rye is not as drought-sensitive as oats, rye being a winter cereal. The differences between the years are also less pronounced than in Fig. 2.

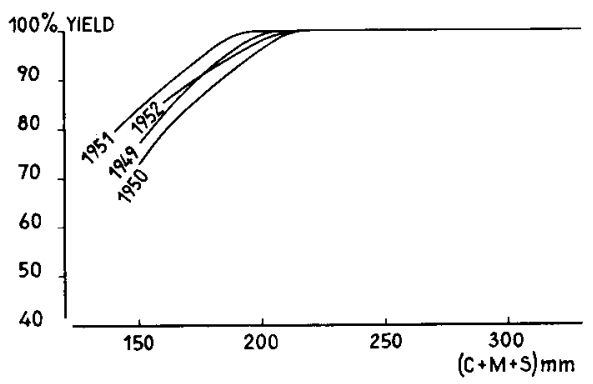

Fig. 3 Relation between $(C+M+S)$ and yields for rye in the years 1948-1952

\section{Farm yield data}

Although many farm yield data are available for the Netherlands, very few are accompanied by somewhat detailed information about soil properties and hydrologic situation. Here use was made of data published by van Eldik (1960 and 1963), van Geneygen (1966) and van Eldik et al. (1966) on yields of oats, rye and potatoes for a number of farms and for groups of farms, in the latter case as an average of the group. On the single farms, sprinkling was applied to some crops, but there was no clear relation between the water gifts mutually nor between the gifts and the precipitation during the growing season.

Some farm data covered ten years or more, but most yield data were available over the period 1954-1958. It appeared that the average yield between 1954 and 1958 never deviated more than $10 \%$ from the average yields over these larger periods. From this it was concluded that the period 1954-1958 represented average conditions fairly well. In order to use comparable data and to implicate as many farms as possible in the research, the averages of 1954-1958 were used. 
Table 1 The relation between drought sensitivity and $(C+M+S)$ values

$$
(C+M+S) \text { value }
$$

very drought-sensitive

drought-sensitive

slightly drought-sensitive

sufficient moisture supply
$150 \mathrm{~mm}$

$190 \mathrm{~mm}$

$220 \mathrm{~mm}$

$260 \mathrm{~mm}$

Of some farms, soil and groundwater conditions were described in connection with a qualification of the drought sensitivity of the farms. From these data presented, a $(C+M+S)$ value was estimated for each farm and a scale was developed relating drought sensitivity to $(C+M+S)$ values. This scale has been given in Table 1 .

Very drought-sensitive are those farms of which the soils have a thin humous top layer (less than $30 \mathrm{~cm}$ ) and the effective root zone is shallow $(50-60 \mathrm{~cm})$. Consequently, the waterholding capacity of the effective root zone amounts to $90-100 \mathrm{~mm}$. The watertable is too low to allow capillary rise. According to Rijtema's data, an additional amount of moisture of $50-60 \mathrm{~mm}$ will be extracted by the crop from the layer below the effective root zone. So the $(C+M+S)$ value of these very droughtsensitive soils becomes $150 \mathrm{~mm}$. Soils with sufficient moisture supply were assumed to have a $(C+M+S)$ value of at least $260 \mathrm{~mm}$. This figure was based upon the results of Fig. 1, 2 and 3. The $(C+M+S)$ values of drought-sensitive and slightly drought-sensitive soils were based in the first place on information on soil and groundwater from the cited literature. In addition, it was observed from Fig. 1, 2 and 3 that the sloping parts of these curves were almost linear, so the $(C+M+S)$ values between the two extremes of Table 1 should relate linearly also. Using the $(C+M+S)$ values of Table 1, the yields of the crops were plotted. Fig. 4 shows the results of

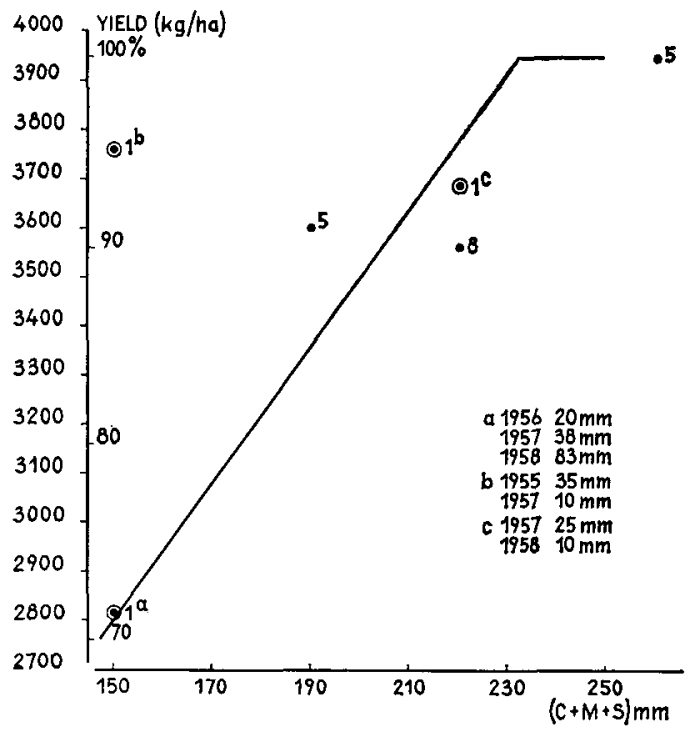

Fig. 4 Yields of summer cereals plotted against $(C+M+S)$ for the years 19541958 


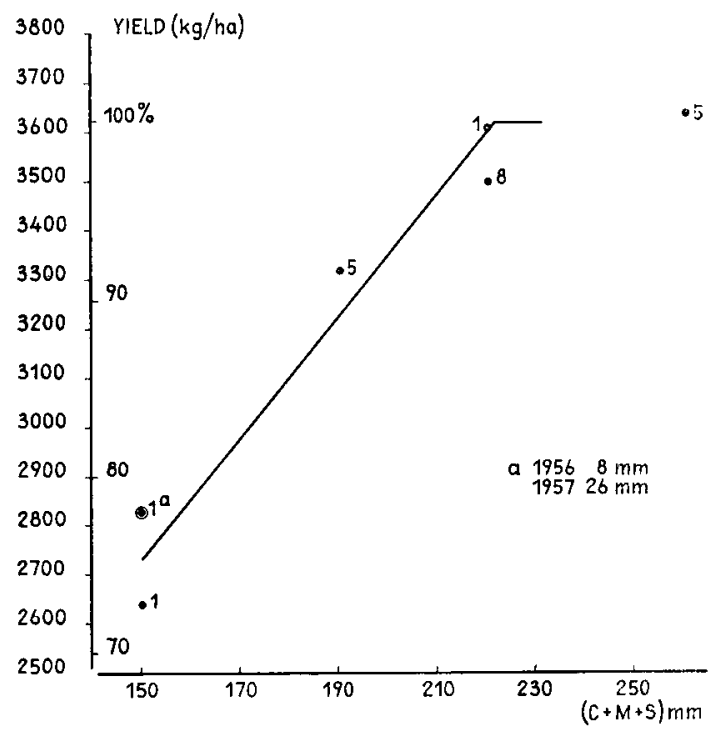

Fig. 5 Yields of rye plotted against $(C+M+S)$ for the years 1954-1958

the summer cereals oats and the mixed crop of oats and barley. The numbers besides each point indicate the number of farms that were involved; 1 means the yield of a single farm, 5 the average yield of a group of five farms. In the case the crop has been sprinkled, the points have been encircled and marked with $a, b$ or c. Corresponding herewith, the amount of sprinkling and the year in which it was applied, have been written right below in the graphs. Two vertical scales have been used: one in $\mathrm{kg} / \mathrm{ha}$ and one in percentages. The relation given in Fig. 4 was assumed to be linear; the given line is close to the one marked with 1951-1953 in Fig. 2. Because considerable sprinkling was involved, the drawn line is not well established, especially not the lower end.

The results of rye have been given in Fig. 5, only one point has been sprinkled. Fig. 5 may be compared to Fig. 3, both graphs agree well.

In Fig. 6 the revenues of all crops together have been plotted expressed in guilders

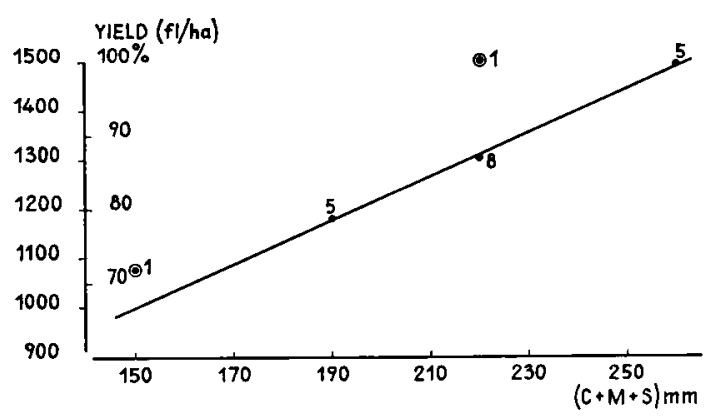

Fig. 6 Crop revenues plotted against $(C+M+S)$ for the years 1954-1958 
(fl.) per ha, this being the form in which the data were available. The revenues of groups of five and eight farms without sprinkler installations are close to a line that is in agreement with the previous results. From the data presented the following conclusions may be drawn:

a. There is a reasonable agreement between the data presented by Sieben and Ferrari on the one hand and those by van Eldik and van Geneygen on the other hand.

b. The average crop yield depressions due to moisture deficiency can be estimated at about $30 \%$ at soils with a $(C+M+S)$ value of $150 \mathrm{~mm}$ and is $0-10 \%$ at soils with a $(C+M+S)$ value of $230 \mathrm{~mm}$ and more. For values between, the relation between $(\mathbf{C}+\mathbf{M}+\mathrm{S})$ and yield is linear as a good approximation. This is valid as an average over a longer period to be taken over wet and dry years both.

\section{Watertable and grass yield}

Besides the relation between crop yield and watertable, Sieben (1955) also published curves giving the relation between grass yield and watertable for the years 1949-1952. Similar research was done by de Boer et al. (1956), who published an average curve over the years 1951-1953. All grass yields are bruto and have been expressed in $\mathrm{kg}$ dry matter per ha.

These data have also been converted into $(C+M+S)$ curves as with the crop yield data. However, here the growing season was taken at 180 days while the maximum and minimum depths of the effective root zone were assumed at 50 and $40 \mathrm{~cm}$ respectively. The results have been given in Fig. 7; here too the horizontal scale has been shortened and yields have been expressed in percentages. All curves marked with the appropriate year are from Sieben, the curve indicated by 1951-1953 has been taken from de Boer. From the graph it may be seen that in 1951 there was no yield depression at all while 1949 had considerable depressions below a $(\mathrm{C}+\mathrm{M}+\mathrm{S})$ of $280 \mathrm{~mm}$.

A completely different source of grass yield data was provided by publications by Jagtenberg (1961, 1962 and 1963), Kop (1961) and van Steenbergen (1967). Herein grass yields of permanent pasture on farms have been published over a long period. A series of 15-19 plots was selected, situated in Gelderland and Twente on sandy soil covering the period 1952-1963. Of these plots the yields, the average watertable for each growing season, and the soil conditions were recorded. From this we calculated a $(C+M+S)$ value for each plot, using the averages of the watertables

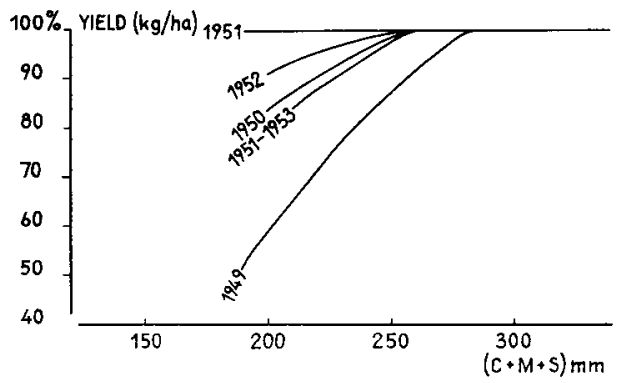

Fig. 7 Relation between grass yields and $(C+M+S)$ for the years 1949-1953 


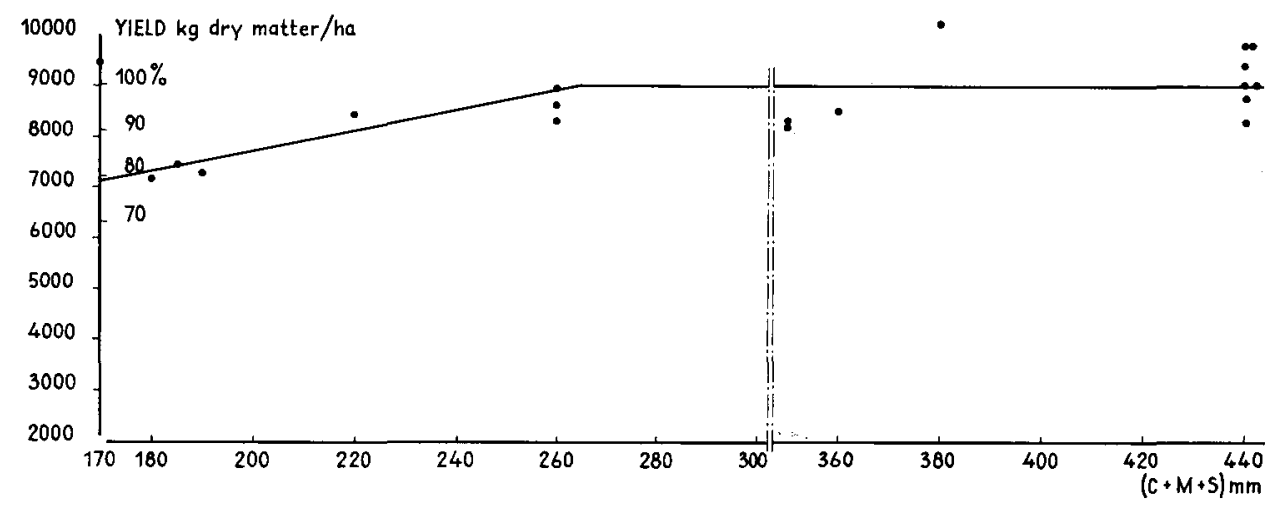

Fig. 8 Relation between grass yields and $(C+M+S)$ for the years 1952-1963

of all growing seasons. Also the yields of each plot were averaged over the years concerned. These yields were plotted against $(C+M+S)$ values and a curve was drawn through the points, assuming a horizontal line at higher $(C+M+S)$ values and a declining branch at lower values. This curve is presented in Fig. 8; compared to Fig. 7, it falls close to the 1950 curve in that figure.

Taking into account that data of a twelve-year period were used, it was assumed that Fig. 8 represents average conditions fairly well and that the curve gives a good estimate of the average yield depression of permanent pasture. Here too the average yield depression has to be taken over dry and wet years both.

\section{Applications}

The calculation of a $(C+M+S)$ value in a given case will strongly depend on the data available. If there is deiailed information on watertables and moisture holding capacities of the soils in an area, the $(C+M+S)$ values of the different soils can be evaluated equally accurate. If the drought sensitivity of soils has to be evaluated on a larger scale, estimates of the watertable and the moisture holding capacity must be made from scanty data. An illustration of the latter case will be given here.

The sandy soils of the Netherlands have been mapped to a considerable extent on a scale $1: 50,000$.

In the classification used, the thickness of the humous top layer is an important characteristic. Applying well chosen estimates for the depth of the root zone and its moisture holding capacity, a value for $\mathrm{S}$ may be established.

In this soil classification, classes of watertables are constructed based upon the upper and lower boundaries of the gleyed horizon as observed at soil profiles in the field. The depths of these boundaries have been correlated to watertables measured over a number of years. From these data the present authors derived an average watertable for the growing season for each class. The calculations performed gave little difference between the average watertable of a growing season of 120 days (AprilJuly) and the one of a 180 days growing season (April-September).

This has been illustrated in Table 2. Each groundwater class has been designated by a Roman numeral. The GHW represents the upper boundary of the gleyed hori- 
Table 2 The different watertable classes as used by the Soil Survey Institute. All values are in $\mathrm{cm}$ below the surface

\begin{tabular}{lrrr}
$\begin{array}{l}\text { Watertable } \\
\text { class }\end{array}$ & $G H W$ & $G L W$ & $\begin{array}{c}\text { Average watertable during } \\
\text { the growing season }\end{array}$ \\
II & - & $50-80$ & 50 \\
III & 40 & $80-120$ & 80 \\
V & 40 & 120 & 120 \\
VI & $40-80$ & 120 & 120 \\
VII & 80 & 120 & 160 \\
& & & \\
\hline
\end{tabular}

zon, the GLW the lower boundary. Classes I and IV have been omitted as they are of little importance for sandy soils.

Using the figures in the fourth column of Table 2, values for $\mathrm{C}$ and $\mathbf{M}$ may be calculated for each watertable class. In this way $(C+M+S)$ values for each combination of soil type and watertable class may be estimated from the $1: 50,000$ soil map. The values in Table 1 show how drought-sensitive the soils are.

As for the yield depressions, these may be estimated from the previous results. In very drought-sensitive soils, yield is depressed by $20-30 \%$, in drought-sensitive soils by $10-20 \%$, and in slightly drought-sensitive soils by $0-10 \%$. It should be emphasized that these yield depressions are averages to be taken over dry and wet years both. Yield depressions due to excess of moisture cannot be estimated in this way.

\section{Conclusions}

This article indicates that Rijtema's suggestion to use one parameter as a characteristic of the drought sensitivity of sandy soils is justified. This conclusion has been based upon a study of crop yields on sandy soils with different moisture holding capacities. The information obtained could only be general for the following reasons. Yield data accompanied by detailed information on soils and hydrological conditions are scarce, so the calculation of the $(C+M+S)$ values of various soils could not be very accurate. A clear relation between annual yields and the distribution of precipitation could not be established. As a consequence, yield depressions could only be calculated as averages over dry and wet years.

The depressions given in this article are somewhat less than those proposed by the Commissie Onderzoek Landbouwwaterhuishouding Nederland (COLN) (1958).

The $(C+M+S)$ parameter will be of help for further research into the subject of yield depressions due to moisture deficiencies, as it reduces the number of yield data necessary. On the other hand, care should be exercised by applying it to soils that differ too much with respect to their capillary properties. Measurement of these properties should be extended to other soil types.

The yield depressions caused by too high watertables cannot be evaluated by this parameter. From the literature it appears that still little is known about this subject.

\section{References}

Boer, Th. A. de \& Ferrari, Th. J., 1956. De samenhang tussen graslandvegetatie, karteringseenheden, bodemvruchtbaarheid en opbrengst in de Gelderse Vallei. Landbouwvoorlichting 13: 686-692. 
Commissie Onderzoek Landbouwwaterhuishouding Nederland - TNO (COLN), 1958. De landbouwwaterhuishouding van Nederland. Rapport nr. 1.

Eldik, J. van, 1960. Bedrijfseconomische resultaten van de beregeningsproefbedrijven over de periode 1954 t/m 1958. Meded. Proefsth Akker-en Weideb. 44.

Eldik, J. van, 1963. Een beregeningsproefbedrijf op weinig droogtegevoelige zandgrond. Resultaten over de periode $1951 \mathrm{t} / \mathrm{m}$ 1961. Meded. Proefstn Akker-en Weideb. 90.

Eldik, J. van \& Bosch, L., 1966. Een beregeningsbedrijf van 72 ha op de Veluwe. Meded. Proefstn Akker-en Weideb. 123.

Ferrari, Th. J., Schans, P. P. H. P. van der \& Sonneveld, F., 1957. Het verband tussen de opbrengst (haver en grasland) en de aan de hand van enkelvoudige profielkenmerken geschatte hoeveelheid beschikbaar vocht. Landbouwk. Tijdschr. 69: 771-778.

Geneygen, J. van, 1966. Een beregeningsproefbedrijf op zeer droogtegevoelige zandgrond. Resultaten over de periode $1954 \mathrm{t} / \mathrm{m}$ 1964. Meded. Proefstn Akker-en Weideb. 122.

Jagtenberg, W. D., 1961. Vijftien jaar bruto-opbrengstbepaling op grasland (1943-1958). Deel 1 . Meded. Proefstn Akker- en Weideb. 57.

Jagtenberg, W. D., 1961a. Vijftien jaar bruto-opbrengstbepaling op grasland (1943-1958). Aanhangsel Deel I. Meded. Proefstn Akker- en Weideb. 57a.

Jagtenberg, W. D., 1962. Vijftien jaar bruto-opbrengstbepaling op grasland. Deel III. Meded. Proefstn Akker-en Weideb. 73.

Jagtenberg, W. D., 1963. Vijftien jaar bruto-opbrengstbepaling op grasland. Deel IV. Meded. Proefstn Akker- en Weideb. 85.

Kop, L. G., 1961. Vijftien jaar bruto-opbrengstbepaling op grasland. Deel II. Meded. Proefstn Akker- en Weideb. 59.

Rijtema, P. E., 1965. An analysis of actual evapotranspiration. Agricultural Research Reports 69.

Sieben, W. H., Smits, H. \& Visser, W. C., 1955. Het verband tussen grondwaterstand en opbrengst in het Veluwerandgebied en de toepassing van dit verband bij het Veluwemeervraagstuk. Directie van de Wieringermeer. (Noordoostpolderwerken. Zwolle. Landbouwkundige afdeling. Bodemkundig onderzoek. Kampen.)

Steenbergen, T. van, 1967. Bruto-opbrengstbepaling op grasland (1959-1963). Meded. Proefstn Akkeren Weideb. 136. 